\title{
Optimal educational climate among students at risk: the role of teachers' work attitudes
}

\author{
Anat Freund $^{1}$ (D) Amit Zriker $^{2,3} \cdot$ Zehava Sapir $^{1}$ \\ Received: 10 February 2020 / Revised: 6 February 2021 / Accepted: 3 March 2021 / \\ Published online: 3 April 2021 \\ C) Instituto Universitário de Ciências Psicológicas, Sociais e da Vida 2021
}

\begin{abstract}
One of the most significant phenomena among students at risk is low resilience. However, very little is known about teacher-related factors that affect students' resilience. Therefore, the main aim of this study was to shed light on the relationships between teacher-level (affective and continuance organizational commitment, professional commitment, burnout, and job characteristics) and student-level variables (optimal educational climate, OEC: the needs of belonging, respect from others, autonomy, self-efficacy, and self-fulfillment), as OEC is viewed as a main source of students' psychological resilience. A sample of 243 teachers and 1777 10th-grade students from 44 nationwide secondary schools in Israel participated in this study. The study included the entire population of this selected cohort. Using hierarchical linear model (HLM) coefficient models, we found two major factors that significantly predicted students' OEC: teachers' affective organizational commitment and teachers' job characteristics. These findings indicate that schools may serve as a protective factor for students at risk, since schools can strengthen teachers' affective abilities in order to ensure their students' psychological resilience. These findings are especially important when working with students at risk, who tend to be exposed to a wider range of stress factors, both individually and academically. The importance of these relationships becomes even greater considering the effects of the COVID-19 epidemic, which has had a significant global impact on many aspects, including students' relationships with schools and teachers.
\end{abstract}

Keywords Students at risk - Optimal educational climate - Psychological resilience ·

Organizational commitment · Professional commitment

Anat Freund

afreund@ research.haifa.ac.il

Amit Zriker

zriker@gmail.com

Zehava Sapir

zehava.sapir@gmail.com

Extended author information available on the last page of the article 


\section{Introduction}

Students at risk are exposed to various stressful factors, such as social, educational, and emotional difficulties, an ongoing need to relate to a group that could potentially lead them to joining delinquent groups, and an increased risk of exposure to cyber hazards (DonitsaSchmidt \& Ramot, 2020). All of these pose environmental and societal difficulties. Many of them do not receive sufficient support from their families and peers, as they tend to come from a deprived social background. Therefore, they seek other sources of support (Worku Mengisto \& Horenczyk, 2019). The professional literature (Moen et al., 2019; Tan et al., 2019) shows that one of the main support systems for these students are their schools, in general, and more specifically their perceived educational climate at school. In addition, the adolescence period contains various challenges: physical, emotional, social, educational, and others (Lovell \& White, 2018). Among many youth at risk, there is not enough family support, and this phenomenon tends to be more complex in the era of COVID-19 (Courtney et al., 2020), as frequent quarantines leave many youths in their homes, with not enough opportunities to meet teachers and peers (Rutledge, 2020). In the current teaching method that tends to involve online and virtual teaching, teachers have even higher responsibility to identify difficulties among their students and giving them support in times of need (Rosenberg et al., 2020).

Therefore, teachers can be depicted as "significant others" in the eyes of their students, by aiding in developing students' emotional and social skills. This may lead to improving students' educational achievements and preventing behavioral problems, such as school dropout (Moen et al., 2019). Regarding students at risk, in particular, teachers can help them to better deal with those social and emotional difficulties that derive from external environments, such as families and neighborhoods (Larose et al., 2020). In order to facilitate this bond between teachers and students, it is vital to strengthen teachers and to foster a well-established commitment to their profession and organization, in an attempt to prevent negative attitudes in the teacher level, such as burnout, and in the student level, such as alienation at school and lack of school belonging.

\section{Psychological resilience of students at risk}

\section{Students at risk: definition of the concept}

Over the years, various definitions and terminologies have been suggested to describe this population, such as "unattached students," "school leavers," or "delinquent students" (Boden et al., 2018). In recent decades, however, all categories have been included under the generic term "students at risk," meaning adolescent pupils who have difficulties in social integration (Devoe et al., 2019), or those characterized by behaviors and attitudes that deviate from the accepted norm (Hirsch et al., 2018).

In this study, students at risk are defined as a group of young learners who are, or may be, in physical, mental, or spiritual stress (Boden et al., 2018; Farrington et al., 2016). This definition includes school students who experience challenging life situations such as school dropout, neglect, emotional abuse, physical or sexual abuse, poverty, delinquency, chronic illness, and difficulties in social relationships (Aud et al., 2011; Chuang et al., 2016).

In the context of the education system, the literature consistently shows a negative link between risk situations among students and their psychological resilience, as students' 
psychological resilience is negatively associated with school dropout, alcohol consumption, and drug use (Butterworth \& Leach, 2017; Hjorth et al., 2016). Therefore, considering the importance of educational climate in fostering students' positive emotions at school, it is vital to investigate this issue, as it may aid students' integration into society and prevent lifethreatening situations.

\section{Life challenges of students at risk and psychological resilience}

The current modern era is characterized by rapid and increasing levels of stress, which pose ongoing threats to children, youth, and adults (Grant et al., 2019). Stressful and significant life events occur intermittently along the life course, disturbing the flow of one's daily routine (Slaten et al., 2015). These often-unexpected events may cause extreme and rapid changes in one's daily existence, create negative feelings, and potentially lead to negative physiological and psychological outcomes (Ashok et al., 2017). Despite this, with proper support from families, peers, communities and other social environments, these pressures and stressors could be weakened and even allow growth to prevent damages in the daily routine (Nelson \& Simmons, 2003).

In this paper, we focus on the term "psychological resilience," defined as one's ability to cope with difficult periods of life, as it relates to the dynamic processes of one's positive adaptation in situations of significant distress (Suárez-Orozco et al., 2018). In general, youths are more vulnerable in situations of stress and risk, since they still have not consolidated a clear and stable psychological network of strengths and coping resources (Dirks et al., 2015). In addition, students at risk usually live in challenging environments, and thus have a high probability of developing psychological distress. The literature has shown that, in most cases, these young people find it difficult to successfully cope with age-related developmental tasks and challenges, and frequently fail to adapt to the environment in a healthy manner (Grant et al., 2019; Sandler et al., 2015).

Students' psychological resilience was found to be consistently correlated with their sense of belonging, in relation to both their schools, their teachers, their pears, and their communities (Fischer et al., 2018). During adolescence, one of the main developmental tasks is to cultivate a sense of belonging in regard to one's social and educational framework (Hadar \& Brody, 2018). Unfortunately, students at risk generally lack this sense of belonging, as they usually live in environments that do not offer many opportunities to develop it (Bartholomew et al., 2018). On the positive side, the literature shows that school teachers can help students develop psychological resilience by strengthening their feelings and perceptions of belonging, being respected by others, and feel autonomous (Ainsworth \& Oldfield, 2019; Taxer et al., 2019). These feelings could lead to improved academic success and individual growth. Students' optimal educational climate (OEC) also plays an important role in their psychological resilience, as literature indicates a strong correlation between teachers' attitudes and students' performance at school (Egalite \& Kisida, 2018; Fischer et al., 2018; Lautenbach \& Antoniewicz, 2018). However, it is not yet known whether and which teachers' work attitudes are most strongly related to students' perceived OEC as means of psychological resilience. This study expresses an endeavor to understand the link between these two: perceived OEC of students and work attitudes of their school teachers.

\section{Optimal educational climate of students at risk}

In order to aid students at risk, it is important to bolster their perceptions regarding their educational systems and to strengthen their psychological resilience, as the relationships between students and 
teachers tend to be important in balancing other relationships in students' lives, which can be extremely challenging (Sampermans et al., 2018). One of the prominent factors in achieving these positive perceptions is students' OEC. More specifically, OEC examines the sense of belonging, respect from others, autonomy, self-efficacy, and self-fulfillment that students feel in their schools. OEC, which is a well-established term, that describe students' feelings in school, relates to two main groups of needs: basic needs and optimal needs (Aldridge \& Fraser, 2016; Astor et al., 2002). The basic needs group is related to satisfying needs associated with psychological and physical wellbeing (Petlak, 2019), as they also appear as such in the self-determination theory of Ryan and Deci (2000). Continuous dissatisfaction regarding one's basic needs can lead to negative emotions. The two basic needs incorporated in this group are the need to belong and to feel respected by others (peers, teachers). Satisfying these two needs is a necessary condition for students' motivation to learn (Allen et al., 2018).

The second group is defined as the optimal needs group. This group contains needs that are not essential to one's basic sense of security, but whose fulfillment advances the individualfrom a neutral state (that could be depicted by boredom or social alienation) to a positive one. These optimal needs can contribute to one's personal growth and development, as well as one's emotional wellbeing (Archambault et al., 2017; Wang \& Degol, 2016; Yu et al., 2018). The three optimal needs included in this group are autonomy, self-efficacy, and self-fulfillment (Cohen \& Garcia, 2008).

Students' perceptions of OEC are vital contributors to their resilience (Wang \& Degol, 2016). Moreover, OEC could fuel students in their path to strive for academic and personal success (Aldridge \& Fraser, 2016). Perceiving their school climate as warm and accepting could enable them to better express their personal values and interests (Archambault et al., 2017). In this study, OEC was considered as based upon five dimensions, as mentioned above, belonging, respect from others, autonomy, self-efficacy, and self-fulfillment. We investigated students' perceptions of OEC (in all five dimensions) as representing their psychological resilience, and explored its relations with teachers' work attitudes and job characteristics.

\section{Teachers' work attitudes}

Employees' work attitudes serve as an important emotional factor that creates various and multiple commitments. Teachers with a stronger commitment to their profession and organization are expected to be more effective and to address their students' needs more efficiently (Thomas et al., 2020). In this study, we investigated several aspects of work attitudes, as the literature shows the importance of these particular attitudes among teachers in general, and more specifically, among teachers working with students at risk (Castrén et al., 2017).

\section{Organizational commitment}

Organizational commitment is defined as the relative prominence of the individual's identification with the organization in which he/she works (Yousef, 2017). This commitment includes active inter-relationships with the organization, so when the individual feels more committed to the organization, he/she tends to invest more efforts for the good of the organization (Meyer et al., 2019). Meyer and Allen (1997) presented two major types of organizational commitment. Firstly, affective organizational commitment relates to employees' belief in their organization's values and goals, and a positive feeling toward the organization's attitudes toward these values. According to this definition, teachers with high levels of affective 
organizational commitment will keep on working in their organization, since they feel they belong to it and share its core values (Akar, 2018; Freund \& Zriker, 2020). In this study, we argue that since teachers' affective organizational commitment is a value-driven work attitude, it will be positively correlated with students' perceptions of the educational climate in their school. This assumption is based upon the notion that school values constitute, among other aspects, concern for its students, aiding students in the learning process, and supporting students mentally and developmentally (Batugal \& Tindowen, 2019; Liu \& Werblow, 2019).

The second type of organizational commitment is continuance organizational commitment, which suggests that the employee remains in the organization as a result of profit and loss considerations and calculations. These relate to teachers' subjective feelings, according to which their investment in the organization is equal to what they receive in exchange from the organization. Teachers with high continuance organizational commitment will remain with the organization because they feel it is worth their while (Jang \& Kandampully, 2018). In this study, teachers' perceptions of students' gratitude are viewed as a type of leverage and a motivator for remaining in their roles and in their organizations, and it is affected by several variables, such as salary (Suhardi et al., 2020), attitudes of supervisors and principals (Collie et al., 2020), and organizational climate (Rivai et al., 2019).

In sum, the first hypothesis proposes that teachers' affective organizational commitment is positively correlated with all dimensions of students' perceived OEC, and the second hypothesis proposes that teachers' continuance organizational commitment is also positively correlated with all dimensions of students' perceived OEC.

\section{Professional commitment}

Professional commitment is the extent to which employees are emotionally related to their profession, which is measured by employees' devotion, the amount of thought and time allocated to the profession. Professionally committed teachers are characterized by the significant allocation of energy to their professional vocation, along with cognitive and emotional dedication. Such teachers are also committed to the objectives of their practice, based on their professional and ethical identification with its core values (Demirok, 2018; Karousiou et al., 2019).

Professional commitment is defined in the literature as the relative prominence of professionals' attitudes regarding their profession, as expressed in their thoughts, ideas, and emotions (Giffords, 2009). Employees with high professional commitment tend to base their work on professional ethics, report good relations with their colleagues, and tend to be more effective at work (Weng \& McElroy, 2012). However, professional commitment may sometimes conflict with other types of commitment, such as organizational commitment. In such cases, employees may find themselves facing conflicting demands: for example, professional values on the one hand and organizational expectations on the other (Mor Barak et al., 2001; Freund \& DrachZahavy, 2007). Since teachers' professional commitment is based upon their professional values - such as giving students an equal opportunity to succeed, cooperating with them, and helping them to develop - the third hypothesis proposes that teachers' professional commitment is positively correlated with all dimensions of students' perceived OEC.

\section{Burnout}

Burnout is another important work attitude, which will be examined in this study as one of the main work attitudes of teachers. Burnout is a phenomenon that was first identified in the 
human resource professions by Freudenberger (1974), who argued that as a result of overrequirements, individuals' coping resources "empty out," leaving them feeling depleted. Maslach and Jackson (1981) defined burnout as a sense of chronic mental, physical, and spiritual fatigue, caused by a continuous and lengthy feeling of emotional over-burden at work. In the literature (Fernet et al., 2012; Maslach \& Jackson, 1986), burnout has three main components. The first component is emotional frailty (the dwindling of emotional and physical resources), the second component relates to de-personalization or cynicism (negative reactions or over-exaggerated indifference to clients and various aspects of work), and the third component includes the deterioration of personal capabilities (feelings of incompetence, having a negative work outlook, and general feelings of work dissatisfaction). Since burnout is a work-related symptom (Näring et al., 2006), we proposed that teachers with a higher burnout levels will be less sensitive toward their students, which could lead to feelings of negativity among students as well and can lead to diminishing their perception of OEC. In sum, we propose that teachers' burnout is negatively correlated with all dimensions of students' perceived OEC.

\section{Teachers' job characteristics}

The current study also included two teachers' job characteristics: professional and organizational experiences. The term "experience" relates to the number of years an employee has worked in an organization or profession. Professional and organizational experiences were found to have a significant effect on employees' attitudes toward their organization and clients (Kahlenberg, 2015). Studies have shown that professional and organizational experiences are of the most important factors in predicting employee's intention to leave and in understanding their attitudes toward their clients. Scholars found that younger employees, with less organizational experience, have a stronger tendency to leave their workplace (Ertas, 2015). It is possible that because of their younger age and fewer years on the job, these employees are still in the relatively early stages of building their professional identity. Therefore, they are more exposed to the wage-earning stressors of their roles, and these stressors tend to be related to increased levels of job burnout, job-related stress, and intention to leave (Kahlenberg, 2015).

Specifically in the teaching field, the literature shows a consistent correlation between teachers' years of experience and their relationships with their students. Most studies report that experienced teachers tend to be less sensitive to their students (Bottiani et al., 2019; Steinberg \& Kraft, 2017). Ansari and Pianta (2019) also showed that more experienced teachers tend to be less sensitive toward their students, hence teacher-student relationships tend to be stronger among less-experienced teachers. Among teachers with fewer years of experience, the level of fatigue tends to be higher, but they also report better relationships with their students (Gavish \& Friedman, 2010).

The current study examines the question of whether teachers' professional and organizational experiences are correlated with their students' perceptions of OEC. More specifically, the fifth hypothesis proposes that teachers' professional experience is negatively correlated with students' perceived OEC: the higher the teachers' years of experience in the profession, the more negative the different dimensions of students' OEC will be. The sixth hypothesis proposes that teachers' organizational experience is positively correlated with students' perceived OEC: the higher the teachers' years of experience in the organization, the more positive the different dimensions of students' OEC will be. 


\section{The present research}

The study's main goal was to examine the relationships between teachers' work attitudes (affective organizational commitment, continuance organizational commitment, professional commitment, and burnout) and job characteristics (professional and organizational experiences), and students' perceptions of OEC (belonging, respect from others, autonomy, selfefficacy, and self-fulfillment).

In order to achieve this goal, we developed six hypotheses as follows: (1) hypothesis 1: teachers' affective organizational commitment will be positively correlated with students' perceived OEC climate; (2) hypothesis 2: teachers' continuance organizational commitment will be positively correlated with students' perceived OEC; (3) hypothesis 3: teachers' professional commitment will be positively correlated with students' perceived OEC; (4) hypothesis 4: teachers' burnout will be negatively correlated with students' perceived OEC; (5) hypothesis 5: teachers' professional experience will be negatively correlated with students' perceived OEC; and (6) hypothesis 6: teachers' organizational experience and students' OEC will be positively correlated with students' perceived OEC.

\section{Methodology and methods}

\section{Study design and sample}

The study was conducted in all 44 secondary schools (both in the Jewish and Arab sectors in Israel) supervised by the Ministry of Labor, Welfare and Social Services in Israel. These schools form a network of educational institutions that educate students at risk, who are associated with various difficulties including behavioral misconduct, drug and alcohol abuse, and mental difficulties (such as depression and anxiety). In sum, the study included 243 teachers and 1777 students from these 44 nationwide secondary schools in Israel. The students were all in the 10th grade. As mentioned, the study included the entire population of this selected cohort (10th-grade students and their teachers). Hence, we did not sample selected schools or regions, but rather surveyed all teachers and 10th-grade students enrolled in this educational network in Israel.

As can be seen in Table 1, most teachers were men $(n=128,52.7 \%)$, married $(n=202$, $86.3 \%)$, and born in Israel $(n=205,81 \%)$. A total of 169 teachers $(69 \%)$ were homeroom teachers. Their mean age was 24.96 years $(\mathrm{SD}=12.24)$, their mean professional experience in teaching was 15.83 years $(\mathrm{SD}=10.99)$, and their mean experience in their current organization was 10.51 years $(\mathrm{SD}=9.45)$.

Regarding students, 1524 (85.8\%) were male. Regarding their religion, 940 (53.1\%) were Jewish, 649 (36.6\%) were Muslim, 100 (5.6\%) were Druze, and 82 (4.6\%) were Christian. Their mean age was 15.74 years $(\mathrm{SD}=0.87)$. The remaining data appears in Table 2.

\section{Research tools}

The research tools were attitude questionnaires, formulated as a series of closed-ended questions and distributed among both students and teachers. The teachers' questionnaire included the following variables: affective organizational commitment, continuous organizational commitment, professional commitment, and burnout, with a 7-point response scale, 
Table 1 Teachers' characteristics $(n=243)$

\begin{tabular}{|c|c|c|c|c|c|}
\hline Variable & Levels & $n$ & $\%$ & $M$ & SD \\
\hline \multirow[t]{2}{*}{ Gender } & Male & 128 & $52.7 \%$ & & \\
\hline & Female & 115 & $47.3 \%$ & & \\
\hline \multirow[t]{4}{*}{ Marital status } & Single & 19 & $8.1 \%$ & & \\
\hline & Married & 202 & $86.3 \%$ & & \\
\hline & Divorced & 12 & $5.1 \%$ & & \\
\hline & Widowed & 1 & $0.4 \%$ & & \\
\hline \multirow[t]{5}{*}{ Country of origin } & Israel & 205 & $81 \%$ & & \\
\hline & Former USSR & 13 & $5.1 \%$ & & \\
\hline & North Africa & 16 & $6.3 \%$ & & \\
\hline & Western Europe & 4 & $1.6 \%$ & & \\
\hline & Other & 15 & $5.9 \%$ & & \\
\hline \multirow[t]{5}{*}{ Educational level } & Matriculation exams only & 6 & $2.4 \%$ & & \\
\hline & Professional diploma & 31 & $12.3 \%$ & & \\
\hline & B.Ed. & 123 & $48.6 \%$ & & \\
\hline & M.Ed. & 69 & $27.3 \%$ & & \\
\hline & Other & 24 & $9.5 \%$ & & \\
\hline \multirow[t]{2}{*}{ Position as class head } & Yes & 169 & $69 \%$ & & \\
\hline & No & 76 & $31 \%$ & & \\
\hline Age & - & - & - & 24.96 & 12.24 \\
\hline Professional experience & - & - & - & 15.83 & 10.99 \\
\hline Organizational experience & - & - & - & 10.51 & 9.45 \\
\hline
\end{tabular}

ranging from 1 (“don't agree at all") to 7 (“totally agree"). The students' questionnaire included the OEC variable, with a 4-point response scale, ranging from 1 ("don't agree at all") to 4 ("totally agree"). Both research groups (teachers and students) also answered a demographic questionnaire.

\section{Students' optimal educational climate}

This tool examines students' feelings of belonging, respect from others, autonomy, self-efficacy, and self-fulfillment at school. For this purpose, we used Erhard's (2001) educational climate questionnaire. This questionnaire contains 37 items in five

Table 2 Students' characteristics $(N=1777)$

\begin{tabular}{lllll}
\hline Variable & Levels & $n$ & $\%$ & $M$ \\
Gender & Male & 1524 & $85.8 \%$ & \\
\multirow{2}{*}{ Religion } & Female & 253 & $14.2 \%$ & \\
& Jewish & 940 & $53.1 \%$ & \\
& Muslim & 649 & $36.6 \%$ & \\
Parents' marital status & Druze & 100 & $5.6 \%$ & \\
& Christian & 82 & $4.6 \%$ & \\
Socio-economic status & Married & 1,416 & $82.4 \%$ & \\
& Divorced/separated & 302 & $7.6 \%$ & \\
& Not good & 112 & $6.4 \%$ & \\
& Medium & 364 & $20.9 \%$ & \\
Age & Good & 612 & $35.2 \%$ & \\
\hline
\end{tabular}


dimensions: sense of belonging $(\alpha=0.82)$, sample item: "I feel that my teachers really care about what is happening to me"; respect from others $(\alpha=0.84)$, sample item: "Other students in my class treat me with honor and respect"; autonomy $(\alpha=0.68)$, sample item: "Teachers encourage students to offer new ideas related to the school"; self-efficacy ( $\alpha=0.74)$, sample item: "I feel I can succeed at school"; and self-fulfillment $(\alpha=0.81)$, sample item: "I can express my skills and talents at school."

\section{Students' demographic questionnaire}

This questionnaire included questions regarding students' gender, religion, parents' marital status, socio-economic status, and age.

\section{Teachers' affective organizational commitment}

In order to measure teachers' affective organizational commitment, we used the questionnaire developed by Allen and Meyer (1990). This questionnaire contains eight items, sample item: "I really feel that the school's problems are my problems" $(\alpha=0.71)$.

\section{Teachers' continuance organizational commitment}

In order to measure teachers' continuance organizational commitment, we used the questionnaire developed by Allen and Meyer (1990). This questionnaire also contains eight items, sample item: "It would be very difficult for me to leave my current school, even if I wanted to" $(\alpha=0.65)$.

\section{Teachers' professional commitment}

In order to measure teachers' professional commitment, we used Kanungo's (1982) questionnaire, which includes 10 items, sample item: "The most important things that happen to me involve my current profession" ( $\alpha=0.86)$.

\section{Teachers' burnout}

The questionnaire used to measure burnout was the Maslach burnout inventory (MBI) scale (Maslach \& Jackson, 1986), which includes 25 statements divided into four dimensions measuring four aspects of burnout: emotional burnout, de-personalization, decrease in personal competency, and emotional restlessness. Originally, each statement was examined according to two measures-intensity and frequency. For the purpose of this research, four statements that relate to de-personalization were used, along with eight statements relating to the perception of personal competency, sample item: "I deal with the problems of those who turn to me with great efficacy" $(\alpha=0.84)$.

\section{Teachers' demographic questionnaire}

This questionnaire included questions regarding teachers' gender, marital status, country of origin, educational level, position as homeroom teachers, professional experience, organizational experience, and age. 


\section{Ethical considerations}

This research was approved by the IRB of the University of Haifa's Faculty of Health and Social Welfare. In accordance with ethical guidelines, all participants were asked to take part in the research and signed a consent form after the initial approach. As students are considered minors, we received an informed consent from their parents/legally authorized representatives. Additionally, since the students were enrolled in the same school as the teachers, we gave special attention to this ethical issue and ensured that no participant could be identified by his/her answers. All questionnaires were anonymous and did not include identifying details such as class, school, and/or name. Furthermore, data were collected by external research assistants, rather than by school staff.

\section{Results}

\section{Correlations among teachers' work attitudes}

Table 3 shows the correlations among teachers' various work attitudes: organizational commitment (both affective and continuance aspects), professional commitment, and burnout. As presented in Table 3, most teachers' work attitudes were significantly and positively correlated with one another. The correlations between both types of organizational commitments (affective and continuance) and burnout were negative. No correlation was found between teachers' continuance organizational commitment and their professional commitment.

\section{Correlations between teachers' work attitudes and students' OEC}

The findings of hypotheses 1 to 4 are presented in Table 4 . In these analyses, it is inferred that teachers' affective organizational commitment was positively correlated with only one of students' OEC dimensions: sense of self-efficacy, albeit this this correlation was rather weak. The remaining four students' OEC dimensions (belonging, respect from others, autonomy, and self-fulfillment) were not significantly correlated with teachers' affective organizational commitment.

Table 4 also shows that teachers' continuance organizational commitment was positively correlated with only students' sense of autonomy. This correlation was also rather weak. The remaining four students' OEC dimensions were not significantly correlated with teachers' continuance organizational commitment. Regarding teachers' professional commitment and burnout (hypotheses 3 and 4), both were not significantly correlated with any of the students' OEC dimensions.

Table 3 Pearson correlations among teachers' work attitudes

\begin{tabular}{llll}
\hline & $\begin{array}{l}\text { Professional } \\
\text { commitment }\end{array}$ & $\begin{array}{l}\text { Continuance } \\
\text { organizational } \\
\text { commitment }\end{array}$ & $\begin{array}{l}\text { Affective } \\
\text { organizational } \\
\text { commitment }\end{array}$ \\
\hline $\begin{array}{l}\text { Continuance organizational } \\
\text { commitment }\end{array}$ & - & - & -0.08 \\
$\begin{array}{l}\text { Professional commitment } \\
\text { Burnout }\end{array}$ & - & 0.12 & $0.30^{* *}$ \\
\hline
\end{tabular}

$* * p<.01$ 
Table 4 Pearson correlations between teachers' work attitudes and students' OEC dimensions

\begin{tabular}{lllll}
\hline & Burnout & $\begin{array}{l}\text { Professional } \\
\text { commitment }\end{array}$ & $\begin{array}{l}\text { Continuance } \\
\text { organizational } \\
\text { commitment }\end{array}$ & $\begin{array}{l}\text { Affective } \\
\text { organizational } \\
\text { commitment }\end{array}$ \\
\hline Belonging & 0.03 & 0.01 & 0.02 & 0.03 \\
Respect from others & 0.02 & 0.02 & -0.02 & 0.04 \\
Autonomy & -0.01 & 0.00 & $0.06^{*}$ & -0.03 \\
Self-efficacy & 0.05 & 0.00 & -0.03 & $0.07^{*}$ \\
Self-fulfillment & 0.04 & -0.01 & -0.03 & 0.04 \\
\hline
\end{tabular}

${ }^{*} p<.05$

In sum, hypotheses 1 and 2 were partially supported by the data. However, hypotheses 3 and 4 were refuted by the data, as we did not find significant correlations between teachers' professional commitment and burnout and students' perceived OEC.

\section{HLM coefficients for predicting students' OEC}

Table 5 shows the results of HLM coefficients for examining the probability of teachers' work attitudes in predicting students' perceived OEC. As presented in the table, teachers' affective organizational commitment predicted three dimensions in students' perceived OEC: respect from others, self-efficacy, and self-fulfillment. The remaining dimensions (sense of belonging and autonomy) were not predicted by teachers' work attitudes.

The collected data had two main levels: the school level (which included the information of 243 teachers' work attitudes in 44 schools) and the student level (which included the information of 1777 10th-grade students in these schools), Considering the state of the nested data, we tested this using a series of HLMs (Bryk \& Raudenbush, 1992), which allowed us to examine multi-level models. The estimation is based on restricted maximum likelihood and provides robust standard errors that can restrict any potential infringement of the study's assumptions. In our study, we used this formula for the student level: $y=\beta_{0}+r$, in which $y$ is the measure of students' OEC, $\beta_{0}$ is the mean level of students' educational climate, and $r$ is the student-level error factor.

Table 5 HLM coefficients and the probability of teachers' work attitudes in predicting students' OEC

\begin{tabular}{|c|c|c|c|c|c|c|c|c|c|c|}
\hline & \multicolumn{2}{|c|}{ Belonging } & \multicolumn{2}{|c|}{ Respect from others } & \multicolumn{2}{|c|}{ Autonomy } & \multicolumn{2}{|c|}{ Self-efficacy } & \multicolumn{2}{|c|}{ Self-fulfillment } \\
\hline & $b$ & $\beta$ & $b$ & $\beta$ & $b$ & $\beta$ & $b$ & $\beta$ & $b$ & $\beta$ \\
\hline $\begin{array}{l}\text { Affective } \\
\text { organizational } \\
\text { commitment }\end{array}$ & 0.10 & 0.06 & $0.09 *$ & 0.25 & -0.08 & -0.03 & $0.24 * * *$ & 0.34 & $0.19^{* *}$ & 0.30 \\
\hline $\begin{array}{l}\text { Continuance } \\
\text { organizational } \\
\text { commitment }\end{array}$ & 0.09 & 0.03 & -0.04 & -0.03 & 0.15 & 0.06 & -0.02 & -0.02 & -0.03 & -0.03 \\
\hline $\begin{array}{l}\text { Professional } \\
\text { commitment }\end{array}$ & 0.03 & -0.01 & 0.04 & 0.01 & -0.01 & -0.02 & -0.01 & -0.02 & -0.01 & -0.02 \\
\hline Burnout & -0.15 & 0.06 & -0.03 & 0.06 & -0.20 & -0.02 & 0.15 & 0.13 & 0.09 & 0.11 \\
\hline
\end{tabular}

$* p<.05, * * p<.01, * * * p<.001$ 
Table 6 shows HLM coefficients for the probability of teachers' professional and organizational experiences in predicting students' perceived OEC. As presented in the table, teachers' professional experience significantly predicted two dimensions of students' perceived OEC: respect from others and self-efficacy. Teachers' organizational experience predicted the very same students' OEC dimensions: respect from others and self-efficacy. These coefficients were statistically significant, albeit rather low. Hence, hypotheses 5 and 6 were partially supported by the data.

\section{Discussion}

The study's main goal was to examine the relationships between teachers' work attitudes (affective organizational commitment, continuance organizational commitment, professional commitment, and burnout) and the perceptions of OEC among students at risk (belonging, respect from others, autonomy, self-efficacy, and self-fulfillment).

In order to achieve this goal, we developed six hypotheses. In the following, we will illustrate these hypotheses and present their results after analyzing the data. In the first hypothesis, we proposed that teachers' affective organizational commitment will be positively correlated with students' perceived OEC climate. This hypothesis was partially supported by the data, as findings show that teachers' affective organizational commitment was positively correlated with only one of the students' OEC dimensions: sense of self-efficacy. In the second hypothesis, we proposed that teachers' continuance organizational commitment will be positively correlated with students' OEC. This hypothesis was also partially supported by the data, as findings show that teachers' continuance organizational commitment was positively correlated with only students' sense of autonomy.

The third hypothesis was that teachers' professional commitment will be positively correlated with students' OEC. Fourth, we proposed that teachers' burnout will be negatively correlated with students' OEC. Both hypotheses were refuted by the data, as the analyses showed that teachers' professional commitment and burnout were not significantly correlated with any of the students' OEC dimensions.

In the fifth hypothesis, we proposed that teachers' professional experience will be negatively correlated with students' OEC, and the sixth hypothesis proposed that teachers' organizational experience will be positively correlated with students' OEC. Both hypotheses were partially supported by the data, as teachers' professional and organizational experience predicted two dimensions of students' perceived OEC: respect from others and self-efficacy.

Table 6 HLM coefficients and the probability of teachers' professional and organizational experience to predict students' OEC

\begin{tabular}{|c|c|c|c|c|c|c|c|c|c|c|}
\hline & \multicolumn{2}{|c|}{ Belonging } & \multicolumn{2}{|c|}{$\begin{array}{l}\text { Respect from } \\
\text { others }\end{array}$} & \multicolumn{2}{|c|}{ Autonomy } & \multicolumn{2}{|c|}{ Self-efficacy } & \multicolumn{2}{|c|}{$\begin{array}{l}\text { Self- } \\
\text { fulfillment }\end{array}$} \\
\hline & $b$ & $\beta$ & $b$ & $\beta$ & $b$ & $\beta$ & $b$ & $\beta$ & $b$ & $\beta$ \\
\hline Professional experience & 0.01 & 0.01 & $-0.02 *$ & -0.16 & 0.01 & 0.02 & $-0.02 *$ & -0.14 & -0.01 & 0.01 \\
\hline Organizational experience & -0.01 & -0.01 & $0.02 *$ & 0.16 & -0.01 & -0.02 & $0.02 *$ & 0.16 & 0.01 & -0.01 \\
\hline
\end{tabular}

$* p<.05$ 
In general, study findings indicate that students' perceived OEC was linked to teachers' affective organizational commitment. The most prominent finding of the data analysis, in relation to teachers' affective organizational commitment, was that teachers' affective organizational commitment predicted three dimensions of students' OEC: respect from others, selfefficacy, and self-fulfillment. We can assume that teachers who have an emotional relatedness to their schools may serve as a positive example to students - causing them to also experience feelings of respect. This behavior on the part of teachers may be expressed by their contribution to establishing proper social relationships, for example, by publicly criticizing bullying, ridicule, and humiliation and encouraging respectful behavior among students (Wachs et al., 2019). An additional positive behavior among teachers, which may provide students with a positive outlook and encourage social learning, is treating students with respect and giving them positive feedback (van der Kleij, 2019).

Another interesting finding was that teachers' affective organizational commitment also predicted students' sense of self-efficacy. This means that teachers who have a higher sense of affective organizational commitment will care more about what happens within the school's walls. Therefore, they will adopt more positive behaviors that will reinforce students' sense of self-efficacy. Some examples of these behaviors include assigning realistic tasks and targets, which are best suited to the students' abilities, and providing positive feedback in relation to learning outcomes and processes (Schwab, 2019).

The third dimension was students' sense of self-fulfillment. The literature shows that teachers with a high level of affective organizational commitment are also characterized by a sense of self-realization which, in turn, can strengthen this feeling among students as well (Ashforth et al., 2016). One explanation for this is that these teachers invest more thought and effort in finding ways to enable each student to express himself/herself and his/her areas of personal interest. This investment on the part of teachers may create an educational climate that provides a safe space within which students may express authentic, unique, and creative opinions, thereby allowing for a higher level of students' sense of self-fulfillment.

All of the above are especially important in relation to students at risk. For these students, positive feelings - such as respect from others, self-efficacy, and self-fulfillment - are of particular importance. Most of these students, over the course of their lives, have experienced harsh failures, a general lack of respect, and a lack of opportunity to express and realize their strengths and areas of interest (Burns \& Rapee, 2016; Grant et al., 2019; Sampermans et al., 2018). Thus, we can assume that teachers' affective organizational commitment can significantly strengthen these students. However, teachers' affective organizational commitment was not related to two students' perceived OEC dimensions: sense of autonomy and belonging. This finding raises questions about the role of the school, which is not a democratic organization, but in many cases is rather characterized by minimizing students' ability to make decisions and influence school procedures (Entwisle, 2018; McInerney et al., 2015). It is possible that teachers' affective organizational commitment was not found to be related to students' sense of autonomy because a teacher with a high level of affective organizational commitment will tend to be more loyal and feel a higher sense of commitment to the school and its values. In this case, the teacher may limit students' autonomy and not allowing them to make independent decisions in areas that are relevant to them - such as dress code issues or recess activities. In relation to students at risk, these skills are of much more importance.

Teachers working with students at risk must hone their ability to regulate their feelings, receive more legitimization for the difficulties they face, and receive clear validation and appreciation for their efforts (Harding et al., 2019). This will help these teachers to better 
support and understand their students. In accordance with the explanation provided above regarding students' social learning based on teachers' behaviors, one can assume that when teachers respond in helpful ways to regulate students, the students can internalize this behavior and learn to better control their feelings and behaviors. This explanation is in line with the research literature that discusses the relationship between teachers' and students' emotional world (Roeser \& Eccles, 2014). This is an important and encouraging finding, since it supports the notion of teachers' influence on students' sense of belonging. Students' sense of belonging at school reflects their experiences of teachers' warmth and concern and their feeling of belonging to their peer group (Won et al., 2018). A positive relationship between teachers and students is related to a higher level of sense of belonging among these teachers, as the sense of belonging is an inherent feature of affective commitment (Sharma \& Dhar, 2016).

Regarding students at risk in particular, sense of belonging at school may be a factor that could provide them with the feeling that they are well-protected, which enhances their resilience and strengthens it. This resilience may help lower their tendency to engage in criminal behaviors, as well as reduce school dropout (Won et al., 2018). As an effect of their resilience, these students can experience feelings of reinforcement regarding their successes and abilities. This is a positive cyclical process, in which the school can bring about a deep change in students' emotional-social world. This change can provide students with the sense that they are valued and appreciated. In addition, this is also a process of enrichment and learning from imitation, in which the students imitate the teachers' sense of belonging.

\section{Conclusions}

Findings show that, generally, teachers have an impact on students' perceived OEC. Therefore, it is crucial that teachers will understand that a sense of connection and meaningful dialog between them and students at risk cannot develop in a vacuum. It is extremely difficult for a single teacher to generate meaningful processes with students at school if the organizational atmosphere does not lend itself to such processes. In order for educational work to be truly meaningful to students at risk, an affective organizational attitude of responsibility and commitment to students' mobility must exist.

Furthermore, teachers must also be committed and willing to acquire an advanced level of professionalism. The ability to create meaningful relationships between teachers and students within an educational framework depends, to a large extent, on the existence of a flexible climate, which encourages openness and changes. These stages are necessary - in the field of education, in general - and they are even more essential when working with students at risk. Working with this population requires tremendous efforts on the part of teachers in order to create meaningful relationships, which serve as a basis for motivating students toward self-realization. The school should be a "good enough" environment, embracing qualities such as flexibility and harmony, which stem from basic human relationships between students and teachers.

\section{Theoretical and practical contributions}

The current study has both theoretical and practical contributions and implications. On the theoretical level, the results shed light on a number of themes. One theme relates to the importance of teachers' affective organizational commitment and work attitudes regarding students' perceived OEC. The current study's contribution is based on the importance of work 
attitudes, specifically affective and continuance organizational commitments, and the way these two affects the perceptions of OEC among students at risk, as a result of the education system's increased protective role. In light of the study's findings, it is important to allocate a more significant amount of resources to help teachers to better cope with the phenomenon of students' perceptions of OEC. It is also important to examine students' feelings at school according to OEC measures as early as possible. This examination can help improve the emotional-social climate at school and can enable the students who study at these schools to experience success in situations where they previously experienced failure.

The finding that relates to the importance of teachers' affective organizational commitment in predicting students' perceptions of OEC is of particular importance. In an era when increasing students' sense of belonging is of a top priority for all education professionals, teachers' affective organizational commitment and its impact on students' OEC highlight the human factor in the educational framework. Hence, decision makers must strive to create a suitable physical environment for students and teachers altogether. It is of manifest importance that decision-makers understand that the teacher is the central figure in this picture. Therefore, it is vital to invest in further developing positive work attitudes among teachers.

\section{Limitations}

The current study has several limitations that may influence the findings. First, the questionnaires included questions of attitudes, based on participants' subjective self-report, which may lead to emotional bias and social desirability. Second, the current study included only students at risk, studying in organizational settings supervised by the Ministry of Labor, Welfare and Social Services in Israel. Future studies should also investigate other populations of students that are not necessarily defined as being "at risk." Third, the design of the study was crosssectional in its nature, hence it has limited power in developing specific practical recommendations. Therefore, it would be wise to conduct an additional longitudinal research in order to bolster its results. Fourth, it is suggested to include other important variables (such as teachers' and students' motivation) and to also include interviews with teachers, students, principals, etc.

Code availability Not applicable.

Author contribution All authors are listed on the title page.

Data availability Not applicable.

\section{Declarations}

Conflict of interest The authors declare no competing interests.

\section{References}

Ainsworth, S., \& Oldfield, J. (2019). Quantifying teacher resilience: Context matters. Teaching \& Teacher Education, 82, 117-128.

Akar, H. (2018). The relationships between quality of work life, school alienation, burnout, affective commitment and organizational citizenship: A study on teachers. European Journal of Educational Research, 7(2), 169-180. 
Aldridge, J. M., \& Fraser, B. J. (2016). Teachers' views of their school climate and its relationship with teacher self-efficacy and job satisfaction. Learning Environments Research, 19(2), 291-307.

Allen, K., Kern, M. L., Vella-Brodrick, D., Hattie, J., \& Waters, L. (2018). What schools need to know about fostering school belonging: A meta-analysis. Educational Psychology Review, 30(1), 1-34.

Allen, N. J., \& Meyer, J. P. (1990). The measurement and antecedents of affective, continuance and normative commitment to the organization. Journal of Occupational Psychology, 63(1), 1-18.

Ansari, A., \& Pianta, R. C. (2019). Teacher-child interaction quality as a function of classroom age diversity and teachers' beliefs and qualifications. Applied Developmental Science, 23(3), 294-304.

Archambault, I., Janosz, M., Dupéré, V., Brault, M. C., \& Andrew, M. M. (2017). Individual, social, and family factors associated with high school dropout among low-SES youth: Differential effects as a function of immigrant status. British Journal of Educational Psychology, 87(3), 456-477.

Ashforth, B. E., Schinoff, B. S., \& Rogers, K. M. (2016). "I identify with her," "I identify with him": Unpacking the dynamics of personal identification in organizations. Academy of Management Review, 41(1), $28-60$.

Ashok, V., Rajan, A., \& Maben, R. (2017). Stressors in adolescence: An analytical cross-sectional study. Indian Journal of Child Health, 4(1), 72-74.

Astor, R. A., Benbenishty, R., Zeira, A., \& Vinokur, A. (2002). School climate, observed risk behaviors, and victimization as predictors of high school students' fear and judgments of school violence as a problem. Health Education \& Behavior, 29(6), 716-736.

Aud, S., Kewal, A., Ramani, A., \& Frohlich, L. (2011). America's youth: Transitions to adulthood (NCES 2012026). National Center for Education Statistics, Institute of Education Sciences.

Bartholomew, K. J., Ntoumanis, N., Mouratidis, A., Katartzi, E., Thøgersen-Ntoumani, C., \& Vlachopoulos, S. (2018). Beware of your teaching style: A school-year long investigation of controlling teaching and student motivational experiences. Learning \& Instruction, 53, 50-63.

Batugal, M. L. C., \& Tindowen, D. J. C. (2019). Influence of organizational culture on teachers' organizational commitment and job satisfaction: The case of catholic higher education institutions in the Philippines. Universal Journal of Educational Research, 7(11), 2432-2443.

Boden, J. M., Sanders, J., Munford, R., \& Liebenberg, L. (2018). The same but different? Applicability of a general resilience model to understand a population of vulnerable youth. Child Indicators Research, 11(1), 79-96.

Bottiani, J. H., Duran, C. A., Pas, E. T., \& Bradshaw, C. P. (2019). Teacher stress and burnout in urban middle schools: Associations with job demands, resources, and effective classroom practices. Journal of School Psychology, 77, 36-51.

Bryk, A. S., \& Raudenbush, S. W. (1992). Hierarchical linear models for social and behavioral research: Applications and data analysis methods. Sage.

Burns, J. R., \& Rapee, R. M. (2016). Screening for mental health risk in high schools: The development of the Youth RADAR. Psychological Assessment, 28(10), 1220-1231.

Butterworth, P., \& Leach, L. S. (2017). Early onset of distress disorders and high-school dropout: Prospective evidence from a national cohort of Australian adolescents. American Journal of Epidemiology, 187(6), 1192-1198.

Castrén, S., Temcheff, C. E., Derevensky, J., Josefsson, K., Alho, H., \& Salonen, A. H. (2017). Teacher awareness and attitudes regarding adolescent risk behaviors: A sample of Finnish middle and high school teachers. International Journal of Mental Health \& Addiction, 15(2), 295-311.

Chuang, C. W. I., Chan, C., \& Leventhal, A. M. (2016). Adolescent emotional pathology and lifetime history of alcohol or drug use with and without comorbid tobacco use. Journal of Dual Diagnosis, 12(1), 27-35.

Cohen, G. L., \& Garcia, J. (2008). Identity, belonging, and achievement: A model, interventions, implications. Current Directions in Psychological Science, 17(6), 365-369.

Collie, R. J., Bostwick, K. C., \& Martin, A. J. (2020). Perceived autonomy support, relatedness with students, and workplace outcomes: An investigation of differences by teacher gender. Educational Psychology, 40(3), 253-272.

Courtney, D., Watson, P., Battaglia, M., Mulsant, B. H., \& Szatmari, P. (2020). COVID-19 impacts on child and youth anxiety and depression: Challenges and opportunities. The Canadian Journal of Psychiatry, 65(10), 688-691.

Demirok, M. S. (2018). Career satisfaction and professional commitment of special education teachers. Quality \& Quantity, 52(2), 1187-1199.

Devoe, D. J., Farris, M. S., Townes, P., \& Addington, J. (2019). Interventions and social functioning in youth at risk of psychosis: A systematic review and meta-analysis. Early Intervention in Psychiatry, 13(2), 169-180.

Dirks, M. A., Persram, R., Recchia, H. E., \& Howe, N. (2015). Sibling relationships as sources of risk and resilience in the development and maintenance of internalizing and externalizing problems during childhood and adolescence. Clinical Psychology Review, 42, 145-155. 
Donitsa-Schmidt, S., \& Ramot, R. (2020). Opportunities and challenges: Teacher education in Israel in the Covid-19 pandemic. Journal of Education for Teaching, 46(4), 586-595.

Egalite, A. J., \& Kisida, B. (2018). The effects of teacher match on students' academic perceptions and attitudes. Educational Evaluation \& Policy Analysis, 40(1), 59-81.

Entwisle, D. R. (2018). Children, schools, and inequality. Routledge.

Erhard, R. (2001). Optimal Educational Climate: A tool for diagnosis and intervention. Jerusalem, IL: The Ministry of Education, Psychological Counseling Service (in Hebrew).

Ertas, N. (2015). Turnover intentions and work motivations of millennial employees in federal service. Public Personnel Management, 44(3), 401-423.

Farrington, D. P., Ttofi, M. M., \& Piquero, A. R. (2016). Risk, promotive, and protective factors in youth offending: Results from the Cambridge study in delinquent development. Journal of Criminal Justice, 45, 63-70.

Fernet, C., Guay, F., Senécal, C., \& Austin, S. (2012). Predicting intra-individual changes in teacher burnout: The role of perceived school environment and motivational factors. Teaching \& Teacher Education, 28(4), 514 525 .

Fischer, C., Fishman, B., Dede, C., Eisenkraft, A., Frumin, K., Foster, B., Lawrenz, F., Levy, A. J., \& McCoy, A. (2018). Investigating relationships between school context, teacher professional development, teaching practices, and student achievement in response to a nationwide science reform. Teaching \& Teacher Education, 72, 107-121.

Freudenberger, H. J. (1974). Staff burnout. Journal of Social Issues, 30(1), 159-165.

Freund, A., \& Drach-Zahavy, A. (2007). Organizational (role structuring) and personal (organizational commitment and job involvement) factors: Do they predict interprofessional team effectiveness? Journal of Interprofessional Care, 21(3), 319-334.

Freund, A., \& Zriker, A. (2020). Do multiple commitments predict job satisfaction in non-profit organizations? A longitudinal analysis. European Journal of International Management, 1(1), 1. https://doi.org/10.1504/ EJIM.2020.10028834.

Gavish, B., \& Friedman, I. A. (2010). Novice teachers' experience of teaching: A dynamic aspect of burnout. Social Psychology of Education, 13(2), 141-167.

Giffords, E. D. (2009). An examination of organizational commitment and professional commitment and the relationship to work environment, demographic and organizational factors. Journal of Social Work, 9(4), $386-404$.

Grant, A. A., Jeon, L., \& Buettner, C. K. (2019). Chaos and commitment in the early childhood education classroom: Direct and indirect associations through teaching efficacy. Teaching \& Teacher Education, 81(1), 50-60.

Hadar, L. L., \& Brody, D. L. (2018). Individual growth and institutional advancement: The in-house model for teacher educators' professional learning. Teaching \& Teacher Education, 75, 105-115.

Harding, S., Morris, R., Gunnell, D., Ford, T., Hollingworth, W., Tilling, K., et al. (2019). Is teachers' mental health and wellbeing associated with students' mental health and wellbeing? Journal of Affective Disorders, $242,180-187$.

Hirsch, R. A., Dierkhising, C. B., \& Herz, D. C. (2018). Educational risk, recidivism, and service access among youth involved in both the child welfare and juvenile justice systems. Children \& Youth Services Review, 85, 72-80.

Hjorth, C. F., Bilgrav, L., Frandsen, L. S., Overgaard, C., Torp-Pedersen, C., Nielsen, B., \& Bøggild, H. (2016). Mental health and school dropout across educational levels and genders: a 4.8-year follow-up study. $B M C$ Public Health, 16(1), 976-987.

Jang, J., \& Kandampully, J. (2018). Reducing employee turnover intention through servant leadership in the restaurant context: A mediation study of affective organizational commitment. International Journal of Hospitality \& Tourism Administration, 19(2), 125-141.

Kahlenberg, R. D. (2015). Tenure: How due process protects teachers and students. American Educator, 39(2), 4-11.

Kanungo, R. N. (1982). Measurement of job and work involvement. Journal of Applied Psychology, 67(3), 341349.

Karousiou, C., Hajisoteriou, C., \& Angelides, P. (2019). Teachers' professional identity in super-diverse school settings: Teachers as agents of intercultural education. Teachers \& Teaching, 25(2), 240-258.

Larose, S., Duchesne, S., \& Châteauvert, G. B. (2020). How does mentoring by teachers improve the adjustment of academically at-risk students in high school? International Journal of School \& Educational Psychology, $8(1), 36-49$.

Lautenbach, F., \& Antoniewicz, F. (2018). Ambivalent implicit attitudes towards inclusion in preservice PE teachers: The need for assessing both implicit and explicit attitudes towards inclusion. Teaching \& Teacher Education, 72, 24-32. 
Liu, Y., \& Werblow, J. (2019). The operation of distributed leadership and the relationship with organizational commitment and job satisfaction of principals and teachers: A multi-level model and meta-analysis using the 2013 TALIS data. International Journal of Educational Research, 96, 41-55.

Lovell, J. L., \& White, J. L. (2018). The troubled adolescent: Challenges and resilience within family and multicultural contexts. Routledge.

Maslach, C., \& Jackson, S. E. (1981). The measurement of experienced burnout. Journal of Occupational Behavior, 2(2), 99-113.

Maslach, C., \& Jackson, S. E. (1986). The Maslach burnout inventory. Consulting Psychologists Press.

McInerney, D. M., Ganotice Jr., F. A., King, R. B., Marsh, H. W., \& Morin, A. J. (2015). Exploring commitment and turnover intentions among teachers: What we can learn from Hong Kong teachers. Teaching \& Teacher Education, 52, 11-23.

Meyer, J. P., \& Allen, N. J. (1997). Commitment in the workplace: Theory, research and application. Sage.

Meyer, J. P., Morin, A. J., Stanley, L. J., \& Maltin, E. R. (2019). Teachers' dual commitment to the organization and occupation: A person-centered investigation. Teaching \& Teacher Education, 77, 100-111.

Moen, A. L., Sheridan, S. M., Schumacher, R. E., \& Cheng, K. C. (2019). Early childhood student-teacher relationships: What is the role of classroom climate for children who are disadvantaged? Early Childhood Education Journal, 47(3), 331-341.

Mor Barak, M. E., Nissly, J. A., \& Levin, A. (2001). Antecedents to retention and turnover among child welfare, social work, and other human service employees: What can we learn from past research? A review and metaanalysis. Social Service Review, 75(4), 625-661.

Näring, G., Briët, M., \& Brouwers, A. (2006). Beyond demand-control: Emotional labour and symptoms of burnout in teachers. Work \& Stress, 20(4), 303-315.

Nelson, D. L., \& Simmons, B. L. (2003). Health psychology and work stress: A more positive approach. In J. C. Quick \& L. E. Tetrick (Eds.), Handbook of occupational health psychology (pp. 97-119). American Psychological Association.

Petlak, E. (2019). School culture and the related issues. Ad Alta: Journal of Interdisciplinary Research, 9(1), 227-233.

Rivai, R., Gani, M. U., \& Murfat, M. Z. (2019). Organizational culture and organizational climate as a determinant of motivation and teacher performance. Advances in Social Sciences Research Journal, 6(2), $555-566$.

Roeser, R. W., \& Eccles, J. S. (2014). Schooling and the mental health of children and adolescents in the United States. In M. Lewis \& K. Rudolph (Eds.), Handbook of developmental psychopathology (pp. 163-184). Springer.

Rosenberg, H., Ophir, Y., \& Billig, M. (2020). OMG, RU OK? Using social media to form therapeutic relationships with youth at risk. Children \& Youth Services Review, 120, 105365. https://doi.org/10.1016/ j.childyouth.2020.105365.

Rutledge, K. (2020). Anticipating the mental health effects of COVID-19 in youth: Social isolation in a digital age. Journal of the American Academy of Child \& Adolescent Psychiatry, 7, 8-11.

Ryan, R. M., \& Deci, E. L. (2000). Self-determination theory and the facilitation of intrinsic motivation, social development, and well-being. American Psychologist, 55(1), 68-78.

Sampermans, D., Isac, M. M., \& Claes, E. (2018). Can schools engage students? Multiple perspectives, multidimensional school climate research in England and Ireland. JSSE: Journal of Social Science Education, 17(1), 13-28.

Sandler, I., Ingram, A., Wolchik, S., Tein, J. Y., \& Winslow, E. (2015). Long-term effects of parenting-focused preventive interventions to promote resilience of children and adolescents. Child Development Perspectives, 9(3), 164-171.

Schwab, S. (2019). Teachers' student-specific self-efficacy in relation to teacher and student variables. Educational Psychology, 39(1), 4-18.

Sharma, J., \& Dhar, R. L. (2016). Factors influencing job performance of nursing staff: Mediating role of affective commitment. Personnel Review, 45(1), 161-182.

Slaten, C. D., Elison, Z. M., Hughes, H., Yough, M., \& Shemwell, D. (2015). Hearing the voices of youth at risk for academic failure: What professional school counselors need to know. The Journal of Humanistic Counseling, 54(3), 203-220.

Steinberg, M. P., \& Kraft, M. A. (2017). The sensitivity of teacher performance ratings to the design of teacher evaluation systems. Educational Researcher, 46(7), 378-396.

Suárez-Orozco, C., Motti-Stefanidi, F., Marks, A., \& Katsiaficas, D. (2018). An integrative risk and resilience model for understanding the adaptation of immigrant-origin children and youth. American Psychologist, 73(6), 781-796. 
Suhardi, M., Huda, S. A., Mulyadi, D., \& Nazopah, N. (2020). The effect of organizational culture, leader behaviors, job satisfaction, and justice on organizational commitment. Journal of Applied Science, Engineering, Technology, \& Education, 2(1), 37-42.

Tan, F. D., Whipp, P. R., Gagné, M., \& van Quaquebeke, N. (2019). Students' perception of teachers' two-way feedback interactions that impact learning. Social Psychology of Education, 22(1), 169-187.

Taxer, J. L., Becker-Kurz, B., \& Frenzel, A. C. (2019). Do quality teacher-student relationships protect teachers from emotional exhaustion? The mediating role of enjoyment and anger. Social Psychology of Education, 22(1), 209-226.

Thomas, L., Tuytens, M., Devos, G., Kelchtermans, G., \& Vanderlinde, R. (2020). Transformational school leadership as a key factor for teachers' job attitudes during their first year in the profession. Educational Management Administration \& Leadership, 48(1), 106-132.

van der Kleij, F. M. (2019). Comparison of teacher and student perceptions of formative assessment feedback practices and association with individual student characteristics. Teaching \& Teacher Education, 85, 175189.

Wachs, S., Bilz, L., Niproschke, S., \& Schubarth, W. (2019). Bullying intervention in schools: A multilevel analysis of teachers' success in handling bullying from the students' perspective. The Journal of Early Adolescence, 39(5), 642-668.

Wang, M. T., \& Degol, J. L. (2016). School climate: A review of the construct, measurement, and impact on student outcomes. Educational Psychology Review, 28(2), 315-352.

Weng, Q., \& McElroy, J. C. (2012). Organizational career growth, affective occupational commitment and turnover intentions. Journal of Vocational Behavior, 80(2), 256-265.

Won, S., Wolters, C. A., \& Mueller, S. A. (2018). Sense of belonging and self-regulated learning: Testing achievement goals as mediators. The Journal of Experimental Education, 86(3), 402-418.

Worku Mengisto, W., \& Horenczyk, G. (2019). Hidden and actual dropout from the education system among adolescents of Ethiopian origin in Israel. Intercultural Education, 30(5), 531-546.

Yousef, D. A. (2017). Organizational commitment, job satisfaction and attitudes toward organizational change: A study in the local government. International Journal of Public Administration, 40(1), 77-88.

Yu, M. V. B., Johnson, H. E., Deutsch, N. L., \& Varga, S. M. (2018). "She calls me by my last name": Exploring adolescent perceptions of positive teacher-student relationships. Journal of Adolescent Research, 33(3), $332-362$.

Publisher's note Springer Nature remains neutral with regard to jurisdictional claims in published maps and institutional affiliations. 
Anat Freund. School of Social Work, University of Haifa, Aba Khoushi 199, Haifa 3498838, Israel. E-mail: afreund@research.haifa.ac.il

Amit Zriker. School of Social Work, Bar-Ilan University, Ramat Gan, Israel; Department of Social Work, Ruppin Academic Center, Emek Hefer, Israel. E-mail: zriker@gmail.com

Zehava Sapir. School of Social Work, University of Haifa, Aba Khoushi 199, Haifa 3498838, Israel. E-mail: zehava.sapir@gmail.com

\section{Current themes of research:}

Organizational behavior in welfare organizations. Work attitudes of employees in various professions and organizations. Intervention with minorities, such as the ultra-orthodox Jewish community. Cultural intervention. Work attitudes of employees in various human services. Community practice in social work. Leadership development among youth. School climate. Resilience. At-risk youth.

Most relevant publications in the field of Psychology of Education:

Freund, A., \& Baruchin, E. (2018). Factors associated with help-seeking among people of the Haredi faith-based community. The Indian Journal of Social Work, 79(4), 497-514.

Freund, A., Cohen, A., Blit-Cohen, E., \& Dehan, N. (2017). Professional socialization and commitment to the profession in social work students: A longitudinal study exploring the effect of attitudes, perception of the profession, teaching, training and supervision. Journal of Social Work, 17(6), 635-658.

Freund, A., Schaedel, B., Azaiza, F., Boehm, A., \& Hertz-Lazarowitz, R. (2018). Parental involvement among Jewish and Arab parents: Patterns and contextual predictors. Children \& Youth Services Review, 85, 194201.

\section{Affiliations}

\section{Anat Freund $^{1} \cdot$ Amit $^{\text {Zriker }^{2,3}} \cdot$ Zehava Sapir $^{1}$}

1 School of Social Work, University of Haifa, Aba Khoushi 199, 3498838 Haifa, Israel

2 School of Social Work, Bar-Ilan University, Ramat Gan, Israel

3 Department of Social Work, Ruppin Academic Center, Emek Hfer, Israel 